\title{
Assessing the effect of domestic resource mobilization on the economic growth of Cameroon
}

\author{
Wujung, Vukengkeng Andrew \\ Aziseh, Fozoh Isiah \\ - ReCeIved: 17 September 2015 \\ - ACCePted: 10 NOVEMBER 2015
}

\begin{abstract}
This paper observes that despite the efforts made to enhance domestic resource mobilization as a means of boosting economic growth in Cameroon, the economy does not seem to grow at the same rate. Against this background, this paper empirically assesses the effect of mobilizing various sources of domestic resources on the economic growth of Cameroon. The empirical investigation is carried out using data from the World Bank's development indicators (WDI, 2014) for Cameroon for the period 19802013. Descriptive statistics and the Instrumental Variable Generalized Method of Moments (IVGMM) were used to analyze the data. The results show that there is a positive and significant relationship between the various sources of domestic resources and economic growth in Cameroon. From a policy perspective, an important conclusion is that in addition to implementing tax reforms, measures such as widening the tax base, finding alternative sources of revenue, and institutional reforms are needed for Cameroon to fund its development programmes.
\end{abstract}

\section{Keywords:}

Domestic resource mobilization. Economic growth, Cameroon.

\section{JEL classification:}

F43, G15, G18.

Wujung,V.A. Lecturer of Economics, Head of Accounting Division, University of Bamenda, P.O.box 39, Bambili, N.W. Region of Cameroon, C) 677948904.Email: vukenkengwujung@yahoo.com

Fozoh Isiah Aziseh, Department of Economics and Management, University of Bamenda, P.O.box 39, Bambili, N.W. Region of Cameroon. 670218404.Email: isiahfozoh@yahoo.com 


\section{Evaluación del impacto de la movilización de los recursos nacionales en el crecimiento económico de Camerún}

Wujung, Vukengkeng Andrew

Aziseh, Fozoh Isiah

\section{Resumen}

En este trabajo se concluye que, a pesar de los esfuerzos realizados para aumentar la movilización de recursos internos en aras de un mayor crecimiento económico en Camerún, el ritmo de crecimiento de dichos aumentos no ha sido seguido por el ritmo de crecimiento económico. En este contexto, este artículo evalúa empíricamente el efecto de la movilización de los distintos capítulos de recursos nacionales en el crecimiento económico de Camerún. La investigación empírica se lleva a cabo con información de los indicadores de desarrollo del Banco Mundial para Camerún en el período 19802013. En el análisis empírico llevado a cabo se utilizan instrumentos de estadística descriptiva y el método de los momentos generalizado con variables instrumentales. Los resultados muestran la existencia de una relación positiva significativa entre las distintas vertientes de los recursos nacionales y el crecimiento económico camerunés. Desde la perspectiva de la actuación política, una conclusión importante es que, además de la implementación de reformas fiscales, para que Camerún pueda financiar sus programas de desarrollo se necesitan medidas como la ampliación de la base imponible, fuentes alternativas de ingresos, y reformas institucionales.

\section{Palabras clave:}

Movilización de recursos naturales, crecimiento económico, Camerún. 


\section{Introduction}

Economic growth can be achieved through the effective mobilization of the necessary resources, both internally and externally. External resources include foreign aid, external debt, foreign exchange trade revenue, and foreign direct investment, among others. Internal resources include domestic savings, domestic credit, and taxes. Today, the mobilization of these resources has gained international prominence, especially following the international economic crises in 2009 when external resource inflows, official development assistance (ODA), foreign direct investments (FDI), diaspora remittances and domestic revenue generation in developing countries dwindled (Tax Justice Network-Africa, 2011). According to African Development Indicators (ADI) (2014), net ODA to Africa for 1960, 1965, 1970, 1975 and 1980 expressed as a percentage of central government expenditure was as high as $27.84 \%, 28.9 \%, 18.19 \%$, $36.17 \%$ and $29.43 \%$ respectively. At the same time, statistics from the ADI (2014) reveal that the external debt stock of Africa as a whole stood at US\$ 468,271,309.3, 4,260,031,333, 6,394,271,117 and 13,523,300,614 for the years, 1965, 1970, 1975 and 1980 respectively. This shows that foreign aid and external debt constituted a substantial portion of the revenue mobilized by African governments.

After independence, and following the increase in oil prices and other products produced in the continent, most African countries diverted from relying on foreign aid to trade or export-led growth as a means of fostering economic growth. This led to export making up an increasingly large share of countries' GDP over time. For instance, export constituted 20.02\%, 25.24\%, 31.14\% 6 and $26.18 \%$ of the GDP of the African continent for the years 1970, 1975, 1980 and 1985, respectively (ADI, 2014). The economic downturn and other restraining activities associated with these external resources resulted in a gradual decline in the relative contribution of such resources to the economies of developing countries, and especially African countries. In fact, many LDCs are highly reliant on exporting a small set of commodities that suffer from large swings in revenues as the prices of these commodities fluctuate on world markets, and so they have always been prone to economic swings domestically. As such, the reliance on external resources has dropped drastically and been replaced by domestic resources. Accordingly, it is fair to say that aid has helped, but will not deliver sustainable growth and development in Africa (NEPAD, 2013), just as many other external forms of resources cannot entirely turn the situation around.

Fairly recently, many countries around the world have redirected their attention to the domestic mobilization of resources because it is hypothesized that greater domestic resource mobilization (DRM) can facilitate higher levels of economic growth and poverty reduction, and can also be a powerful means of enhancing policy space and domestic ownership (Culpeper and Bhushan, 2008). Domestic resource mobi- 
lization was recognized as a top priority by the Monterrey Consensus on Financing for Development in 2002, and gained significant attention on the G20 agenda in 2013 (OECD, 2014).

In 2011, this led African heads of states and governments to stress the need to transform existing political will on DRM into concrete policy responses and actions. As a result, there has been an increase in various sources of these domestic resources, such as domestic savings, domestic credit, taxes, rents, royalties and so on. For Africa, domestic credit as a percentage of the continent's GDP was 51.69\%, 53.28\%, 55.90\% in 2000, 2005 and 2010 respectively; gross domestic savings as a percentage of GDP was $20.17 \%$ in 2000, 22.105 in 2005, 24.27\% in 2008 and slightly decreasing to $20.79 \%$ in 2010 (ADI, 2010). At the same time, taxes as a percentage of GDP in Africa was $17.26 \%$, $20.88 \%$ and $21.32 \%$ in 2004, 2006 and 2008 respectively, while royalties and licences mobilized in Africa have steadily increased, generating US\$1,597,574,378, $1,791,777,627,2,296,828,407,2,474,567,579,2,459,818,301,2,663,537,674$, and $2,779,470,684$ in the years from 2005 to 2011 respectively (ADI, 2014).

This reveals an increasing rate of DRM. For taxation in particular, it should be seen as an opportunity to shift accountability back from donors to countries' own citizens, creating a more stable and more legitimate state in the process (OECD, 2014). African countries raise more than US $\$ 520$ billion annually from domestic taxes compared to the US\$59 billion that the continent receives in private flows and US\$50 billion in ODA; an indication that there is a huge potential tax revenue if tax administration could be improved (NEPAD, 2013). At the same time, stock market capitalization in the continent rose from US\$300 billion in 1996 to US\$1.2 trillion in 2007 indicating that the continent's stock exchange markets are also a promising platform for raising domestic finance.

Given the resource potential of these sources of development finance and the encouraging performance of some of them, Africa could be expected to robustly respond to a considerable portion of its infrastructure deficits, which today prevent the continent's economies from reaching middle income level (NEPAD, 2013). Nevertheless, Sub-Saharan Africa has the lowest savings rate of any developing region. In 2005, gross domestic savings in the region represented $17.6 \%$ of GDP, compared with $26.0 \%$ in South Asia, 24.0\% in Latin America and the Caribbean, and nearly 42.9\% in East Asia and Pacific countries (World Bank, 2007).

At the same time, the continent's growth rate has fluctuated in response to this changing preference of resources and in line with changing economic circumstances. For instance, the GDP of the continent was $4.45 \%$ in $1980,2.82 \%$ in $1985,2.26 \%$ in $1990,3.06 \%$ in $1995,3.69 \%$ in 2000 , and $5.30 \%$ in 2005 , before dropping to 
4.74\% in 2010 (ADI, 2014). This indicates that the continent has been growing, and at a faster rate in the post crises period.

The situation in Cameroon is no different. From independence through the period of economic turmoil, up to the era of the adoption of the structural adjustment programme and implementation of the growth and employment strategy paper, there has been a continually increasing mobilization of both domestic resources such as taxes and domestic savings and external resources in the form of aid and FDI. However, the nation's reliance on external financing, especially foreign aid, is declining in favour of a growing preference for domestically generated revenues such as taxes and domestic savings. For instance, external debt stock as a percentage of the country's GNI in the 1980s and 1990s was far higher than what it has been in the 2000s, with percentages as high as $49.12 \%$ in 1989 and $107.45 \%$ in 1999 , but just $14.68 \%$ in 2009. The net ODA it received (\% of GNI) has also been in continuous decline from $5.78 \%$ in $1970,4.71 \%$ in $1980,4.16 \%$ in 1990 , down to $2.31 \%$ in 2010 (WDI, 2014). All this indicates a general decline in the inflow of these external resources.

With respect to domestic resources, their rate of mobilization shows a continuous increase. For instance, gross savings (\% of GNI) in Cameroon has increased from $6.26 \%$ in 1980 , to $16.9 \%$ in 1990 , slightly dropping to $16.13 \%$ in 2000 and then to $13.02 \%$ in 2010. Tax revenue as a percentage of GDP in 1990 was $9.77 \%$ rising to $11.2 \%$ in 1999 (ADI, 2014) and is currently a major contributor to state revenue. Royalties and licences have also been on the rise in recent years, particularly as a result of the exploitation of natural resources such as minerals, forests, waters and so on.

Corruption and negative perceptions of tax officials are major issues, especially in Burundi and Cameroon (North-South Institute, 2010). This tends to hinder the use of taxation as an instrument to mobilize domestic resources. Moreover, the financial sector is highly fragmented between formal institutions such as banks, semi-formal ones such as microfinance organizations, and informal arrangements, thereby hampering private resource mobilization in the continent.

Despite all of the above difficulties, Cameroon's transformation into a high growth nation has been a fundamental objective of its major economic programmes since independence. In order to meet this objective, there is an acute need for resource mobilization both domestically and externally. Given the conditionalities and vulnerability of the economy associated with the inflow of external resources, increasing attention has been paid to domestic rather than external resource mobilization (Khan, 2011) in order to foster economic growth in the country. For instance, foreign aid remains a major source of finance in the country but is quite volatile, heavily concentrated and dependent on the priorities (often geopolitical or strategic, including security consider- 
ations) of development partners (UNCTAD, 2006a) and may not take into consideration the development priorities of the recipient country. As such, several reforms, especially those following the implementation of the structural adjustment programme (SAP) have been enacted in order to mobilize domestic resources. These include reforms related to the tax code, the restructuring of the financial or banking sector, stock market capitalization and so on. On the recommendations of the SAP, the tax base and some tax rates have been increased as shown by the introduction of the value-added tax (VAT) in 1999. Moreover, there has been an increase in the exploitation of mineral resources by both domestic and foreign investors, generating greater domestic resources in the form of royalties and licences. The Douala stock exchange market has been rendered operational, though with a timid enrollment as far as quoting of shares is concerned. All these initiatives represent a bid to accelerate economic growth in the country.

Following these reforms and policies, there has been marked improvement in the amount of domestically generated revenues. For instance, there has been growing revenue (as a percentage of GDP) from all telecommunication services ( $0.85 \%, 1.43 \%$, $3.12 \%$ and $3.8 \%$ for $1995,2000,2005$ and 2010 respectively); indirect tax revenue has risen over time, going from $6.69 \%$ in 1995, 7.76\% in 2000, and $9.26 \%$ in 2005 to $9.78 \%$ in 2007 (NIS, 2010); gross domestic savings increased from $13.83 \%$ in 1995 to about $16.14 \%$ in 2000 (ADI, 2014); while domestic credit to the private sector (\% of GDP) increased from $8.2 \%$ to $8.23 \%, 9.88 \%$ and $13.21 \%$ for the years 1995,2000 , 2005 and 2010, respectively (ADI, 2014).

Irrespective of this restructuring and increased focus on the mobilization of domestic resources, the economy does not seem to grow at the same rate as the increase in these resources. For instance, GDP growth (annual \%) for Cameroon was 4.13\%, $4.17 \%, 2.3 \%$ and $3.27 \%$ for the years 1995, 2000, 2005 and 2010, respectively (WDI, 2014) whereas the equivalent increases in domestic credit, tax revenue and domestic savings were double these levels for the same period. This could lead some to question whether the intention of mobilizing domestic resources is actually to foster economic growth in the country.

Unfortunately, very few studies (except for Khan, 2010, 2011) have centred on DRM domestic resource mobilization in Cameroon. In fact, no study has comprehensively examined the effect of the mobilization of these domestic resources on economic growth in Cameroon. This creates a knowledge gap and in order to address said gap, this paper assesses the effect of mobilizing various sources of domestic resources on economic growth in Cameroon.

The paper is structured as follows: Following this introduction, section two reviews the related literature and section three discusses the method of analysis. Empirical 
evidence of the effect on economic growth of mobilizing domestic resources, among other variables, is reported in section four. Section five concludes the paper with some policy implications.

\section{Literature review}

\subsection{Conceptual issues}

The two basic concepts under consideration in this paper are those of domestic resources and economic growth. A domestic resource could be anything from domestic financial capital, human capital, social capital to natural resources (Culpeper and Bhushan, 2008). This means that the term 'domestic resource' generally refers to the labor force, mineral deposits, stocks of money and other national wealth. According to the North-South Institute (NSI) (2010), DRM refers to savings and investments generated by both the public sector (primarily through taxation) and the private sector (as a channel for private savings by households and domestic firms.)

However, this paper takes domestic resources to include fiscal and financial resources generated within the domestic economy. Such resources include taxes (on incomes, corporations, property and goods and services), royalties and licences, tourism income, domestic savings and domestic credit. These resources accrue to either the state (taxes, royalties, tourism income), to the private sector (domestic credit to private sector) or both to the state and the private sector (gross domestic savings, tourism revenue).

As previously pointed out, the mobilization of these resources is vital. Domestic resources are potentially the biggest source of long-term financing for sustainable development and the life blood of all state governance, such as the provision of public goods and services. In turn, they can help strengthen fiscal institutions because stable and predictable revenue facilitates long-term fiscal planning, which can help ensure that resources are allocated to priority sectors and are translated into outcomes. In fact, DRM reduces an economy's dependence on external flows, which are often highly volatile; allows governments greater flexibility in designing and controlling their development agenda; conditions states to improve their domestic environment and the management of public affairs, which creates a conducive environment for foreign investments; enhances national ownership over development processes; and strengthens the bonds of accountability between governments and their citizens (UNCTAD, 2005).

At the same time, the existing institutions and their quality determine the amount of domestic resources that can be mobilized as well as the way in which they are mobilized. Indeed, the effectiveness of the judiciary, security offices and other frameworks 
has reduced the resource mobilization process to a stalemate, as illustrated by the poor quality of contract enforcement, property rights, shareholder protection and so on. This tends to propagate rent-seeking attitudes from authorities in the form of corruption, which in turn compromise the rationality behind the mobilization of domestic resources and impede development as a whole.

The Monterrey Consensus highlights the right conditions for enabling the mobilization of domestic resources as an essential prerequisite for development. Unfortunately, DRM is hampered by factors ranging from slow economic growth, underdeveloped financial systems, low savings, pervasive corruption, weak tax policy, capital flight, unemployment, low income, and high dependency (Keiji et al., 2007; Odhiambo and Ziramba, 2014; Alade et al., 2003; Khan, 2010, 2011; North-South Institute, 2010; Tax Justice Network-Africa, 2011).

Meanwhile, the increased capacity of an economy to produce goods and services compared to a preceding time period is an important concept used in the paper. Economic growth is defined as a positive change in the national income or the level of production of goods and services by a country over a certain period of time. This is often measured in terms of the level of production within the economy. Other possible measures include total factor productivity, factors of production such as technological change, human capital (see the Schumpeterian approach), real per capita GDP or the rate of physical capital accumulation, among others. (Odedokun, 1988; King and Levine, 1993; Allen and Ndikumama, 1998).

Both economic and non-economic factors play a role in determining economic growth in countries around the world. Such factors include capital formation, natural resource endowment, foreign trade conditions, human resources, technical knowhow / general education, social organization, corruption, desire to develop, technology, and political stability (Edwards, 1998).

\subsection{The nexus between domestic resource and economic growth}

Many studies have been carried out around the world that use different methodologies to examine the link between the various forms of domestic resources and economic growth. Some of these studies place the emphasis on taxes and growth, savings and growth/income, or domestic credit and growth, while others focus on royalties from the exploitation of natural resources and growth.. Among such studies are those of Cardenas and Escobar (1998) who use a first-order vector autoregression to examine the question of causation of the growth rate and the savings rate for the period 1925-94 in Colombia. They find a perfect correlation between changes in national savings and changes in investment and that savings Granger-cause growth. Similarly, 
an earlier work by Edwards (1996) finds that the coefficient on the rate of growth in per capita GDP is significantly positive in a private savings regression, and seems to provide some support to the hypothesis that there is a vicious circle in effect.

Adopting the methodology proposed by Toda and Yamamoto (1995), which uses a technique that is applicable irrespective of the system's integration and conintegration properties, Mavrotas and Kelly (2001) investigate the causality between growth and savings. They do so in order to avoid the problems and possible misleading inferences associated with the asymptotic nature of Granger causality testing in time-series studies. For the relationship between GDP, gross domestic savings and private savings analyzed for India and Sri Lanka, the authors find no causality between GDP growth and private savings in India, but show that there appears to be a bi-directional causality between private savings and growth in Sri Lanka. They thus conclude that the existing evidence on the subject should be treated with caution, given the inappropriateness of the econometric methodology adopted in most of the previous empirical studies using time-series data.

Anoruo and Ahmad (2001) utilize cointegration and the vector error-correction modelling technique (VECM) to explore the causal relationship between economic growth and the growth rate of domestic savings for Congo, Ivory Coast, Ghana, Kenya, South Africa, and Zambia. They test for the long-run relationship between economic growth and the growth rate of domestic savings in the context of the Johansen and Juselius (1990) framework, as well as conducting the Granger-causality test to determine the direction of causality between economic growth and the growth rate of domestic savings. The results of the cointegration tests suggest that there was a long-run relationship between economic growth and the growth rate of savings such that economic growth prima facie causes domestic savings growth for most of the countries in their sample.

Ramesh (2006) analyses the relationship between domestic savings and economic growth for many countries with different income levels. The study considers 25 countries, including 10 high income countries (HIC), and the rest mostly focusing on developing countries including 5 upper-middle income countries (UMC), 5 lower-middle income countries (LMC), and 5 low-income countries (LIC). By applying the VECM to the relationship between domestic savings and economic growth for different income levels, it can be seen that for high income countries (HIC) the direction of causality runs from economic growth rate to growth rate of savings, except for Singapore which has a compulsory savings system. Furthermore, the result indicates that there is bi-directional causality in upper-middle income countries (UMC). The direction of causality runs from the growth rate of savings to economic growth rate, and at the same time runs from economic growth rate to the growth rate of savings. However, the study does not find any causality between the growth rate of savings and economic growth rate in Ecuador. 
Ciftcioglu and Begovic (2010) use panel data analysis to investigate whether savings promote growth in a sample of Central and Eastern European countries, employing the Classical Pooled Regression model. The results suggest that the domestic savings rate exerted a statistically significant effect on the growth rate of GDP over the study period. The authors thus recommend specific growth-enhancing policies aimed at increasing both the growth rate of total factor productivity and the rate of accumulation of human capital stock.

Domestic credit mobilization is yet another important related domestic resource which is quite closely linked to domestic savings. Its effect on, or relationship with, growth has also been empirically investigated in many studies. For instance, Wa (2005) in a study of bank credit and economic growth in Macao, shows that the elasticity of output with respect to bank credit has fluctuated over time and exhibited a downward trend. In addition, the contribution of domestic bank credit has been less significant in this growth process, as large-scale tourism projects have been largely financed by foreign funds. This is contrary to the findings of Dey and Flaherty (2005) who use a two-stage regression model to examine the impact of bank credit and stock market liquidity on GDP growth. They find that bank credit and stock market liquidity are not consistent determinants of GDP growth but that banking development is a significant determinant of GDP growth.

For their part, Mishra et al. (2009) examine the direction of causality between India credit market development and economic growth between 1980 and 2008 by using VAR. The authors find that economic growth has a positive impact on credit market development. In addition, Granger Causality Tests indicate that credit market development spurs economic growth in India. These findings corroborate those of Cappiello et al. (2010) who in their study of the Eurozone, find that the supply of credit, both in terms of volumes and in terms of credit standards applied on loans to enterprises, has a significant impact on real economic activity. That is to say, a change in loans growth has a positive significant impact on GDP.

Similarly, using the ARDL approach and error correction model (ECM), lqbal et al. (2012) find that national savings and credit to the private sector play an important role in the economic growth and development of Pakistan. Thus, they conclude that credit to the private sector has significant impact on economic growth, in both the long and the short run.

In a Multivariate VAR Framework, Olaniyi (2013) investigates the relationship between domestic credit and economic growth in Nigeria, using annual time-series data from 1970 to 2012 . The findings reveal that there is a bi-directional causality 
and positive relationship between domestic credit and economic growth in Nigeria. That is, not only does domestic credit contribute positively to economic growth in Nigeria, but the impact is strong and statistically significant.

Economic theory suggests that mineral resources foster the process of local economic development. Through the exploitation of mineral resources, the welfare level of a community can be improved, according to the productive structures and characteristics of each territory. In an earlier study, Sachs and Warner (1997), claim that economies with a generous endowment of natural resources tend to grow more slowly than economies which do not have these resources. They label this phenomenon the "natural resources curse", and the evidence indicates that the resources that are most detrimental to economic growth are minerals and petroleum.

Within a local context in Colombia, Perry and Olivera (2010) use cross-sectional data to analyse the role of oil and coal rents in the development of municipalities. They find, among other things, that oil and coal production have a positive and significant impact on the municipalities' economic development levels. They also find that coal production has a positive impact on the economic development of departments, whereas there is a negative relation with oil production.

From the above review, it can be seen that previous studies have focused on the effect(s) of single or separate aspects of DRM on economic growth and development. The current paper pools these domestic resources together to determine their effect on economic growth of Cameroon. However, other studies such as that of Acemoglu and Robinson (2012) highlight the fact that the endowment of natural resources (and thus their mobilization) is not relevant as far as a country's drivers of economic development are concerned. It can thus be seen that there is far from universal agreement as to whether (DRM) affects growth or not.

\subsection{Theoretical framework}

The Harrod-Domar growth model (Harrod, 1939; and Domar, 1946) is a conventional tool that throws light on the economic growth rate derived from the productivity of capital and the savings level. This model states that aggregate savings are directed to investment. According to the Harrod-Domar growth model, the growth rate of an economy is dependent on two important factors: the savings level and capital-output ratio of the economy.

Assuming that: investment is equal to savings; the economy is making full use of capital stock; the economy is at full employment; there is no government interven- 
tion (the economy is closed) and no depreciation, the model holds that the rate of growth in GDP will be sustainable if the growth rate of capital stock and labor is the same as income growth rate (warranted rate of growth).

In this framework, the model further asserts that there is a capital-output ratio $(k)$, a given level of national savings $(S)$, which is a proportion of the national income, and that since the economy is closed, the investment $(I)$ is determined by the amount of savings.

Nonetheless, the general implication from the above framework is that the growth rate of an economy has a positive correlation with the average propensity to save $(s)$ such that the more savings or investment in an economy, the greater the growth rate of national income (GDP). On the contrary, however, the GDP growth rate has a negative relationship with the national capital-output ratio; the higher the national capital-output ratio, the lower the growth of national income (GDP). The fundamental weakness of the above model, which makes its widespread applicability somewhat limited, hinges on the fact that it is largely built on unrealistic assumptions.

Nevertheless, it is a logical framework in which the incorporation of savings (a form of domestic resource) represents a suitable channel for DRM for economic growth. Moreover, within the ambit of this model, other forms of domestic resources can be mobilized in the same way to promote economic growth.

Another theoretical foundation of this paper is Wagner's law (1973) of increasing state activities. This law observes that there is a general tendency for public expenditure to increase steadily in most countries and that this spurs economic growth. This law predicts that the development of industrial economies will be accompanied by an increasing share of public expenditure in GDP. This forecast is made on the assumption that there is no private ownership of revenue, and that there is a good relationship between the state and its citizens. According to this law, the welfare state is ushered in by the shortcomings of capitalism.

Interpreting Wagner's law, Musgrave (1959) holds that as nations industrialize, the size of the public sector increases steadily. He attributes this to the increasing social, administrative/protective and welfare functions of the state.

Singh (2008) compares different countries at different periods and shows that in progressive societies the rate of economic activities increases when central and local governments assume new functions. The situation improves when these governments perform these functions efficiently. 
The principal criticisms of Wagner's law relate to his view of history and of the relationship between the state and its citizens. Also, when the theory was developed it was not predicted that private individuals could possess revenue for expenditure and hence economic growth. Peacock and Wiseman (1961) also queried whether Wagner's ideas could be applied to all societies at all times and suggested that the time pattern of actual public expenditure growth did not fit well with Wagner's law.

Nevertheless, Wagner's theory indicates that: the activities of the central and local government increase on a regular basis in progressive societies; the increase in government activities is both extensive and intensive; governments undertake new functions in the interest of society; the old and the new functions are performed more efficiently and completely than before; the purpose of government activities is to meet the economic needs of the people; and that the expansion and intensification of government function and activities lead to increased public expenditure. Though Wagner studied the economic growth of Germany, it also applies to other countries, both developed and developing. The framework therefore provides a channel for DRM as it incorporates public expenditure mostly stemming from taxation, royalties, and domestic credits.

\section{Methodology}

Ex post facto research design is employed in the study given that the effects of the independent variables on the dependent variable have already occurred and so cannot be influenced in any way. Secondary data on the various forms of domestic resources, including domestic savings, domestic credits, and natural resources rents (royalties), are used.

\subsection{Model specification and estimation}

The model first specified in this research reflects a double logarithm linear CobbDouglas function modified to incorporate certain important variables that affect the economic growth in Cameroon. The relationship is econometrically stated as follows:

$$
\log \text { Growth }=\beta_{0}+\beta_{1} \log S A V_{t}+\beta_{2} \log D C_{t}+\beta_{3} \log T A X_{t}+U_{t}
$$

Where

Growth = economic growth measured by changes in GDP;

$S A V=$ domestic savings; 
$D C=$ domestic credit provided by the banking sector;

$T A X=$ axes made up of or instrumented by direct and indirect taxes (with royalties and licences included);

$\log =$ natural log of variables;

$U=$ stochastic or error term;

$t=$ time element to illustrate the time-series structure of the data;

$\beta_{0}, \beta_{1}, \beta_{2}$ and $\beta_{3}$ are parameters to be estimated.

The a priori expectations of this functional relationship are that: $\beta_{0}>0, \beta_{1}>0, \beta_{2}>0$ and $\beta_{3}>0$.

To incorporate the dynamic nature of growth due to variations in the level of mobilization of domestic resources, the estimation technique adopted for this study was the Instrumental Variable General Method of Moments (IVGMM) technique. The starting point of the GMM estimation is a theoretical relation that the parameters should satisfy. The idea is to choose the parameter estimates so the theoretical relation is satisfied as "closely" as possible. The theoretical relation that the parameters should satisfy is the condition of orthogonality between some (possibly nonlinear) function of parameters $f(\beta)$ and a set of instrumental variables:

$E(f(\beta) Z)=0$, where $Z$ represents the set of instrumental variables.

Given the identification property of the models or equations presented in this method, other estimators may combine the information in different instruments to produce an estimate with less sampling variability. The most efficient way to combine multiple instruments is usually with the Generalized Method of Moments (GMM). In this way, GMM takes the information in a set of instruments and neatly boils it down to a single instrument.

\subsection{Validation of parameters}

The appropriateness of the parameters of the model were tested on the basis of economic or a priori criteria, the statistical or first-order test and the econometric or second-order test. The economic or a priori test enabled us to determine the magnitude (size) and direction (sign) of the estimated parameters. The statistical test confirmed the statistical significance and the explanatory power of parameters and estimates produced. Statistical problems associated with regression analysis, especially autocorrelation or serial correlation, was tested by means of the Durbin-Watson test. A test for autocorrelation, stationary, and unit root was carried out using the DickeyFuller (DF) test, as well as a test for causality and robust standard errors to test for heteroskedasticity. 


\section{Empirical findings}

\subsection{Phillip-Perron (PP) test for unit root in variables}

The intention behind this test is to ascertain whether or not the time-series data is stationary since non-stationary data may result in spurious regression. The decision rule for the existence of unit root is based on the hypothetical premise that:

If the Mackinnon p-value for $z(t)$ is greater than $10 \%$ then there is a unit root problem. With respect to this rule, this paper finds no unit root problem with the variables. The results from the PP test conducted to this end are presented in Table 1.

\section{Table 1. Results of the PP test for unit root}

\begin{tabular}{|c|c|c|c|c|c|c|}
\hline \multirow[b]{2}{*}{ Variables } & \multirow[b]{2}{*}{$P>z(t)$} & \multirow[b]{2}{*}{ PP Test statistic } & \multicolumn{3}{|c|}{ Critical values } & \multirow{2}{*}{ Stationarity } \\
\hline & & & $1 \%$ & $5 \%$ & $10 \%$ & \\
\hline GDP & 0.0576 & -2.805 & -3.702 & -2.980 & -2.622 & First difference \\
\hline Gross savings & 0.0032 & -3.774 & -3.702 & -2.980 & -2.622 & First difference \\
\hline Domestic credit & 0.0011 & -4.061 & -3.702 & -2.980 & -2.622 & Levels \\
\hline $\begin{array}{l}\text { Natural resource } \\
\text { rents }\end{array}$ & 0.0000 & -6.380 & -3.702 & -2.980 & -2.622 & Levels \\
\hline Tax revenue & 0.0000 & -4.911 & -3.702 & -2.980 & -2.622 & First difference \\
\hline
\end{tabular}

SOURCE: COMPUTED BY AUTHORS, 2015.

As shown in Table 1, all the variables are stationary with domestic credit and natural resource rents being stationary at the level, while GDP, savings and other taxes are stationary after the first difference. As a result, we conclude that there is no unit root problem.

\subsection{Summary statistics}

The basic statistics analyzed in this study are essentially the mean and standard deviations of the variables. Table 2 summarizes the basic statistics of the variables of interest in the study.

As shown by the statistics in Table 2, the average GDP in local currency units (LCU) for the period of study was 6,280 billion FCFA deviating from this mean by 3,590 billion FCFA. At the same time, the mean annual growth rate of Cameroon's GDP for the 34 years under study was approximately $2.82 \%$ with a very high deviation of close to $5 \%$. Furthermore, the average level of domestic savings in Cameroon for the period was 1,080 billion FCFA with a mean deviation of 422 billion FCFA. The average share 
of gross savings in the country's GDP for the period was approximately $19.4 \%$ with this average share deviating by approximately $4.54 \%$.

\section{Table 2. Summary statistics}

\begin{tabular}{lccc}
\hline Variables & Measure & Mean & Standard deviation \\
\hline \multirow{2}{*}{ GDP } & LCU (FCFA) & $6.28 \mathrm{e}+12$ & $3.59 \mathrm{e}+12$ \\
\cline { 2 - 4 } Gross savings & Growth (\%) & 2.824453 & 4.937069 \\
\hline \multirow{2}{*}{ Domestic credit } & LCU (FCFA) & $1.08 \mathrm{e}+12$ & $4.22 \mathrm{e}+11$ \\
\hline \multirow{2}{*}{ Natural resource rents } & LCU (FCFA) & 19.14482 & 4.547251 \\
\cline { 2 - 4 } & $\%$ GDP & $9.85 \mathrm{e}+11$ & $3.79 \mathrm{e}+11$ \\
\hline \multirow{2}{*}{ Tax revenue } & LCU (FCFA) & 18.86637 & 7.46061 \\
& \%GDP & $7.09 \mathrm{e}+11$ & $3.88 \mathrm{e}+11$ \\
\hline
\end{tabular}

SOURCE: COMPUTED BY AUTHORS, 2015.

Within the same period, domestic credit was 985 billion FCFA representing an average annual percentage of GDP of $18.87 \%$ with the absolute and relative figures deviating from the mean by 379 billion FCFA and $7.46 \%$. Meanwhile, the average level of natural resource rents mobilized in Cameroon from 1980 to 2013 was about 709 billion FCFA with a mean deviation for the period worth 388 billion FCFA, representing an average percentage of GDP of $12.04 \%$. Finally, other forms of taxes averaged above 431 billion for the period under study, representing an average annual percentage of GDP of $6.25 \%$.

\subsection{Correlation analysis}

This section of the paper is intended to establish the relationship between the respective elements or forms of domestic resources and their interrelationships.

Table 3. Correlation matrix results

\begin{tabular}{|c|c|c|c|c|c|}
\hline Variables & GDP & $\begin{array}{c}\text { Gross } \\
\text { savings }\end{array}$ & Domestic credit & $\begin{array}{c}\text { Natural } \\
\text { resource rents }\end{array}$ & Other taxes \\
\hline GDP & 1.0000 & & & & \\
\hline Gross savings & $0.9321^{\star * *}$ & 1.0000 & & & \\
\hline Domestic credit & $0.7100^{\star \star \star}$ & $0.6574^{\star * *}$ & 1.0000 & & \\
\hline Natural resource rents & $0.8638^{\star \star \star}$ & $0.8745^{\star \star *}$ & $0.4569^{\star * \star}$ & & \\
\hline Tax revenue & $0.9014^{* * *}$ & $0.8387^{\star * *}$ & $0.4552^{\star \star \star}$ & $0.8872^{\star * *}$ & 1.0000 \\
\hline
\end{tabular}


The correlation results above show that there is a positive and significant relationship between the various forms of domestic resources themselves and their relationship with economic growth (GDP) in Cameroon, with the relationship between the various forms of domestic resource and economic growth being both very strong and positive. It is worth noting that domestic credit and the various forms of taxes are positively but weakly correlated.

\subsection{Elasticities estimates of DRM in Cameroon}

Having ascertained the stationarity of the variables and controlled for other time-series econometric disturbances such as heteroskedasticity, and having instrumented taxes by direct taxes and indirect taxes (natural resource rents/royalties included), we present the GMM regression results in Table 3. The GMM offers the advantage that it allows economic models to be specified while avoiding often unnecessary assumptions, such as specifying a particular distribution for the errors, and it also addresses the issue of omitted variables and influential outliers thereby correcting the problem of heteroskedasticity. Moreover, the GMM does not impose any restrictions on the distribution of the data used in the study. This method also permits us to add moment conditions by assuming that past values of explanatory variables, or even past values of the dependent variable, are uncorrelated with the error term. The results of the GMM estimation are shown in Table 4.

\section{Table 4. Elasticities estimates of domestic resources}

\begin{tabular}{llccc}
\hline LOG GDP & Coefficient & Robust Std. Err. & z-Statistic & Prob. \\
\hline LOGGDS & $0.8682313^{\star \star *}$ & 0.1592222 & 5.45 & 0.000 \\
\hline LOGDCPS & $0.1301882^{\star \star}$ & 0.0657602 & 1.98 & 0.048 \\
\hline LOGTAX & $0.1736271^{\star \star}$ & 0.0803812 & 2.16 & 0.031 \\
\hline Cons & -2.832088 & 2.393527 & -1.18 & 0.237 \\
\hline Number of observations & 34 & & & \\
\hline $\boldsymbol{R}$-squared & 0.9188 & & & \\
\hline Adjusted $R$-squared & 0.9106 & & & \\
\hline Wald chi2(3) & 463.45 & & & \\
\hline Prob $>$ chi2 & 0.0000 & & & \\
\hline
\end{tabular}

SOURCE: ESTIMATED BY AUTHORS, 2015.

Note: (**) and (***) indicate significant at the 0.05 and 0.01 level of significance, respectively.

The model estimated can therefore be specified as follows;

$\log$ Growtht $=-2.832088+0.868231 \log S A V_{t}+0.1301882 \log D C_{t}+0.1736271 \log T A X_{t}$ 
The empirical findings presented above indicate that all forms of domestic resources in Cameroon positively influence the economic growth of the country, implying that positive changes in DRM in Cameroon are a possible means of promoting economic growth in the country. Specifically, the empirical results show that increasing the mobilization of tax as a domestic resource by $100 \%$, boosts national GDP by approximately $17.4 \%$, as expected. This effect is also found to be statistically significant at the $5 \%$ level, given the probability value of its coefficient.

The coefficient of the elasticity of domestic savings shows that the savings rate in Cameroon has a positive effect on economic growth and reveals that doubling the level of savings in Cameroon would lead to approximately an $87 \%$ increase in the GDP of the economy. This is as expected and also significant at the $1 \%$ level of significance. The finding is also in line with the empirical results of Cardenas and Escobar (1998) who examine the question of causation for Colombia by using a first-order vector autoregression of the growth rate and the savings rate for the 1925-1994 period.

Similarly, the coefficient of domestic credit is positive and significant, implying that increments in domestic credit have the potential to increase economic growth in Cameroon. The results show that a $100 \%$ increase in the level of domestic credit granted to the private sector through banks can boost economic growth in Cameroon by approximately $13.02 \%$, in accordance with our expectations. The empirical findings are further estimated to be statistically significant at the $5 \%$ level of significance. The findings are also in line with those of Mishra et al. (2009), who analyzed the direction of causality between India's credit market development and its economic growth be tween 1980 and 2008 by using VAR.

However, the coefficient of multiple determination (Adjusted $R$-squared) shows that approximately $91.1 \%$ of the variation in Cameroon's economic growth can be attributed to the joint variation in the mobilization of the shortlisted domestic resources (tax, savings and domestic credits) with the remaining $8.09 \%$ of the variation accounted for by other growth-related factors. The overall significance of these results are verified by the high value of the Wald chi2, acting as the F-ratio in this case, and its probability value whose 0.0000 value indicates that the empirical results are $99 \%$ reliable for policy prescriptions.

The empirical findings of this study show that DRM through taxation contributes significantly and positively to changes in Cameroon's GDP and thus to its economic growth. Within the context of the Cameroonian economy, taxes constitute the main source of government revenue mobilized through direct and indirect taxes. In a more progressive tax structure, greater resource mobilization through income taxes will increase the provision of basic social and economic infrastructures such as transport, 
communication, education, and health, the externalities of which enhance the productivity of other existing factors of production such as labor and capital, thereby increasing national output. Additionally, such tax revenues are also used to subsidize production activities in the country, especially those of farmers, thereby increasing GDP and thus growth.

However, in order to avert the Laffer effect in which increases in the tax rate eventually reduce tax revenue, the required increase in tax revenue cannot be effectively achieved by raising the tax rate. Rather, it would require a broadening of the tax base by increasing the number of activities that are taxed (as is presently the case in Cameroon, though tax rates remain high). This may also require the strengthening of tax offices, reformed incentive structures, and so on.

Growth models emphasizing capital accumulation (e.g. Solow and AK models) hold that higher savings rates should foster growth because higher savings imply higher capital investment. Indeed, within the ambit of the Harrod-Domar growth model, the GDP growth rate has a positive correlation with the average propensity to save. As such, the more savings or investment in an economy, the greater the growth rate of national income (GDP). Indeed, accumulated savings can be considered as the sources of capital stock which play a crucial role in creating investment, production, and employment.

In a developing country such as Cameroon, in which both private and public savings rate are generally low due to low levels of income, and whose production levels are within their production possibility frontiers, higher savings increases the collateral that can be pledged by the local entrepreneur. This in turn makes it easier to encourage entrepreneurial effort while guaranteeing a sufficient profit share for a foreign investor to participate in an innovation project (Aghion and Howitt, 2005).

As Uremadu (2000) argued, the demand for credit can be directed through loan applications by individuals, corporate entities or the government, as well as through the sale of all classes of interest-bearing assets as a means of raising credit. Therefore, firms raise credit through the sale of bonds, while government does the same to finance budget deficits by borrowing directly from the banking system or through the sale of securities (treasury certificates, municipal bonds and development stocks, etc.) in the financial markets.

However, individuals (consumers), businesses and governments, need credit for investment and consumption purposes. In both directions, the demand for credit for either purpose helps to boost economic growth in the country. For instance, when individuals borrow for consumption, the aggregate demand for goods and services 
increases, causing investments -by means of the accelerator principle- to more than double. This boosts the output and thus growth of the country. On the other hand, greater demand for credit (loanable funds) for investment purposes, the higher the level of investments in the country, propelling the rate of industrialization and thus economic growth of the country.

In general, the mobilization of domestic resources for development is important in that it is potentially the biggest source of long-term financing for sustainable development. As such it can contribute to strengthening fiscal institutions because stable, predictable revenue facilitates long-term fiscal planning which can help ensure that resources are allocated to priority sectors and are translated into outcomes. Moreover, domestic resources are an important antidote to long-term aid dependency and allow increased ownership and policy space to implement strategies that reflect development priorities. According to UNCTAD (2005), DRM reduces an economy's dependence on external flows, which have been found to be highly volatile; allows governments greater flexibility in designing and controlling their development agenda; conditions states to improve their domestic environment and the management of public affairs, which create a conducive environment for foreign investments; enhances national ownership over development processes; and strengthens the bonds of accountability between governments and their citizens. Cameroon is no exception to this.

\section{Conclusion and policy implications}

This paper assesses the effect of DRM on economic growth in Cameroon. The empirical results indicate that various sources of domestic resources (taxes, savings and domestic credit) all positively and significantly promote economic growth in Cameroon. Jointly, variations in these domestic resources account for more than $90 \%$ of the variation in economic growth. Though the rate of DRM in Cameroon has been relatively low, it is found to be a valuable means of filling the resource gap the country faces as it attempts to boost economic growth. The empirical results have shown that mobilization of taxes, domestic savings and domestic credits are key to sustaining economic growth in the country. From a tax policy perspective, an important conclusion is that policymakers in Cameroon should expand the tax base and reduce tax rates. This can be achieved by broadening the range of taxes in order to minimize economic distortions and by equalizing marginal rates, increasing revenues, and enhancing fiscal legitimacy. In addition, this will require curbing the illegal business activities in the informal sector, forcing them to become formal and liable to paying taxes. There is a need to automate the business processes and procedures of tax administration in Cameroon as this would eliminate the element of discretion on the 
part of tax officials and reduce corruption in the tax sector. Also, tax officials should be trained in current auditing methods to enable them to audit multinational companies. The government should also provide adequate resources in terms of remuneration, equipment and machinery and a conducive work environment for tax officials in Cameroon. Moreover, the government can boost private savings by promoting linkages between formal and informal financial institutions, which would facilitate small and medium-sized enterprises' (SMEs) access to financial services, and by further developing the nascent Cameroon capital markets. This can be done by promoting investments, which requires a reduction in the presently high costs of doing business that discourage private investment and consequently generate negative effects on income and savings.

Furthermore, there is a pressing need for improvement in Cameroon's capital markets, such as the Douala Stock Exchange. Such markets should be tasked with improving access to financial services or domestic credits, both for potential savers and potential borrowers, as well as expanding the portfolio of savings and investment products available.

Moreover, the viability of capital markets can be improved by promoting regional equity markets, especially by drawing on existing economic regional integration within the CEMAC region. In fact, expanding the provision of micro-savings, micro-insurance, micro-credits, venture capital and long-term financing would help provide savers and investors in Cameroon with the products best-suited to their needs. Also, there is a need for greater competition in the banking sector requiring the removal of barriers to entry. Minimum requirements and punitive banking charges need to be brought under control.

Finally, the international community can do much more to support domestic resource mobilization DRM in Cameroon. This can be done by increasing assistance aimed at enhancing tax capacity, ensuring greater coherence across aid, trade and investment.

\section{References}

Acemoglu, D. and Robinson, J. (2012): Why Nations Fail, Crown Business. ADI (2010), African Development Indicators, World Bank, Washington.

Aghion, P. and Howitt, P. (2005).Growth with Quality-Improving Innovations: An Integrated Framework, Handbook of Economic Growth, in: Philippe A. and Durlauf, S. (ed.), Handbook of Economic Growth, edition 1, volume 1, chapter 2, pp. 67-110, Elsevier, Amsterdam.

Aghion, P. and Howit, P. (2006). Appropriate growth policy: A unifying framework, Journal of the European Economic Association, 4(2-3), pp. 269-314. 
Alade, S.O., Ajayi, M., Enendu, C.I. and Idowu, E. (2003). The Supply of, and Demand for Loanable Funds, in Nnanna O.J., Alade, S.O. and Odoko F.O. and Garki, A. (eds). Contemporary Economic Policy Issues in Nigeria, Central Bank of Nigeria (CBN), Garki, Abuja, Nigeria.

Anoruo, E. and Ahmad Y. (2001). Causal Relationship between Domestic Savings and Economic Growth: Evidence from Seven African Countries, African Development Review, 13(2), pp. 238-249.

Bhushan, A. and Samy, Y. (2012), Aid and Taxation: Is Sub-Saharan Africa Different? The North-South Institute, Ottawa, May 2012, available at http://www.nsi-ins.ca/wp-content/uploads/2013/02/2012-Aid-and-Taxation.pdf. $\square$

Cappiello, L., Kadareja, A., Sørensen, C.K. and Protopapa, M. (2010). Do Bank Loans and Credit Standards have an effect on Output? A Panel Approach for the Euro Area, European Central Bank Working Paper Series, № 1150 / January.

Cardenas, M. and Escobar, A. (1998). Saving Determinants in Colombia: 1925-1994, Journal of Development Economics, 57(1), pp. 5-44.

- Ciftcioglu, S. and Begovic, N. (2010). Are domestic savings and economic growth correlated? Evidence from a sample of Central and East European countries, Problems and Perspectives in Management, 8(3), pp. 30-35.

Culpeper, R. (2008). Enhancing Domestic Resource Mobilization, G-24 Policy Brief, No. 25, UNDESA, New York, available at www.g24.org/PolicyBriefs/pbno25.pdf.

Culpeper, R. and Aniket, B. (2008). Domestic Resource Mobilisation in Sub-Saharan Africa: A Neglected Factor in Development Strategy. Background paper prepared for Workshop on Domestic Resource Mobilization in SubSaharan Africa, The North-South Institute, Ottawa, Canada.

Dey, M.K. and Flaherty, S. (2005). Stock Exchange Liquidity, Bank Credit, and Economic Growth, Paper presented at the Max Fry Conference on Finance and Development, University of Birmingham, The Business School University House, Birmingham B15 2TT.

Domar, E. (1946). Capital Expansion, Rate of Growth, and Employment, Econometrica, 14(2), pp. 137-147. doi:10.2307/1905364. JSTOR 1905364.

Edwards, S. (1998). Openness, Productivity and Growth: What Do We Really Know?, Economic Journal, 10(8), pp. 383-398.

Forgha, N.G. (2008). Capital Flight, Measurability and Economic Growth in Cameroon: An Econometric Investigation, International Review of Business Research Papers, 4(2) pp. 74-90.

Harrod, R.F. (1939). An Essay in Dynamic Theory, The Economic Journal, 49(193), pp. 14-33. doi:10.2307/2225181. JSTOR 2225181.

Iqbal, M., Ahmad, N. and Hussain Z. (2012). Impact of Savings and Credit on Economic Growth in Pakistan, Pakistan Journal of Social Sciences (PJSS), 32(1), pp. 39-48.

Johansen, S. and Juselius, K. (1990). Maximum Likelihood Estimation and Inference on Cointegration-with Applications to the Demand for Money, Bulletin of Economics and Statistics, 52(2), pp. 169-210.

Khan, S. (2010). Domestic Resource Mobilization in Sub-Saharan Africa: The Case of Cameroon, The North-South Institute, Ottawa, Canada.

Khan, S. (2011). Volatility of Resource inflows and Domestic Investment in Cameroon, African Economic Research Consortium, Research paper 221, Nairobi. 
King, R.G. and Levine, R. (1993a). Finance and Growth: Schumpeter Might Be Right, Quarterly Journal of Economics, 108, pp.717-738.

King, R.G. and Levine, R. (1993b). Finance, Entrepreneurship, and Growth: Theory and Evidence, Journal of Monetary Economics, 32(3), pp. 513-542.

Knack, S. (2001). Aid Dependence and the Quality of Governance: A Cross-Country Empirical Analysis, World Bank Working Paper 2396, Washington.

Mavrotas, G. and Kelly, R. (2003). Savings and financial sector development: panel co-integration evidence from Africa, WIDER Discussion Paper, Helsinki.

Mishra, P.K., Das, K.B. and Pradhan, B.B. (2009). Credit Market Development and Economic Growth in India, Middle Eastern Finance and Economics, 5, pp. 92-107, http://www.eurojournals.com/MEFE.htm.

Musgrave, R.A. (1959). The Theory of Public Finance: A Study in Public Economy, McGraw-Hill, New York.

n NEPAD (2013). Mobilizing Domestic Financial Resources for Implementing NEPAD National and Regional Programmes \& Projects - Africa looks within, NEPAD Planning and Coordinating Agency and UN Economic Commission for Africa Final Report, http://www.un.org/africarenewal/sites/www.un.org.africarenewal/files/ DRM_ENGLISH_REPRO_OP.pdf.

North-South Institute (2010). Domestic Resource Mobilization in Africa, The North-South Institute, Ottawa, Canada.

Odedokun, M.O. (1998). Financial intermediation and economic growth in developing countries, Faculty of Commerce, University of Swaziland, Swaziland.

Odhiambo, O. and Ziramba, E. (2014). Mobilising Domestic Resources for Development Financing In Namibia Constraints and Opportunities, International Policy Centre for Inclusive Growth, Working Paper No. 127.

OECD (2010). External Debt in Africa, Policy Brief No. 10, OCDE Development Centre, Paris.

Olaniyi, E. (2013). On the Causality between Domestic Credit Aggregates and Economic Growth in a Multivariate VAR Framework: Evidence from Nigeria, MPRA Paper No. 51731 posted 29, http://mpra.ub.uni-muenchen. de/51731/.

OECD (2010). Effective Mobilization of Domestic Resources By LDCs, Ministerial meeting on enhancing the mobilization of financial resources for least-developed countries' development, Lisbon, 2-3 October 2010, http://unohrlls. org/UserFiles/File/Effective\%20mobilization\%20of\%20domestic\%2Oresources\%20by\%20LDCs\%2023-09.pdf. $\square$

Peacock, A.T. and Wiseman, J. (1961). The Growth of Public Expenditure in the United Kingdom, Scandinavian Journal of Development Alternatives, 2 \& 3, pp. 241-254.

Perry, G. and Olivera, M. (2010). El impacto del petroleo y la minería en el desarrollo regional y local en Colombia, CAF Working Papers No. 51, Caracas, Venezuela.

Ramesh, M. (2006). Causal Relationship between savings and economic growth in countries with different income levels, Economics Faculty Journal Articles, Paper 20, Bryant University, http://www.accessecon.com/pubs/EB/ 2006/Volume5/EB-05E20002A.pdf.?

Sachs, J. and Warner, A. (1997). Natural Resource abundance and economic growth, Harvard Institute for International Development, Boston. 
Singh, S.K. (2008). Public Finance in Theory and Practice, S .Chand, New Delhi.

Tax Justice Network - Africa (2011). Raising Domestic Resources to Finance Development in Africa. A Project of Tax Justice Network - Africa.

Toda, H.Y. and Yamamoto, T. (1995). Statistical Inference in Vector Auto-regressions with Possibly Integrated Processes, Journal of Econometrics, 66(1-2), pp. 225-250.

UNCTAD (2005). The Least Developed Countries Report 2005: Developing Productive Capacity. United Nations, Geneva.

UNCTAD (2006). The Least Developed Countries Report 2006: Developing Productive Capacity, United Nations, Geneva.

UNCTAD (2007). Reclaiming Policy Space: Domestic Resource Mobilization and Developmental States, Economic Development in Africa, United Nations, Geneva.

Uremadu, S.O. (2000). Modern Public Finance: Theory and Practice, Mindex Publishing Company Ltd., Benin.

Wa, H. (2005). Bank Credit and Economic Growth in Macao, Monetary Authority of Macao, Macao. Wagner, R.E. (1973). The Public Economy, Markham, Chicago.

World Bank (2007). Doing Business Database, (Washington D.C.: World Bank) Data downloaded October 15, 2007 http://www.doingbusiness.org/ExploreTopics/TradingAcrossBorders/.

World Bank (2014). World Development Indicators, http://www.data.worldbank.org/sites/default/files/wdi-2014book.pdf.? 